\title{
The Suitability of Chemical Products and Other Short-Term Remedial Methods for the Control of Cyanobacterial Blooms in Freshwater Ecosystems
}

\author{
Jean-François Humbert ${ }^{1 *}$ and Catherine Quiblier ${ }^{2,3}$ \\ 1 INRA-Institute of Ecology and Environmental Sciences, Sorbonne Université, Paris, France, ${ }^{2}$ Unité Molécules de \\ Communication et Adaptation des Microorganismes (MCAM, UMR 7245), Muséum National d'Histoire Naturelle, Paris, \\ France, ${ }^{3}$ Département Sciences du Vivant, Paris Diderot University, Paris, France
}

Keywords: cyanobacteria, cyanotoxins, freshwater ecosystems, management, chemical products

\section{INTRODUCTION}

OPEN ACCESS

Edited by:

Carolyn Gay Palmer,

Rhodes University, South Africa

Reviewed by:

Fiona Dyer,

University of Canberra, Australia

*Correspondence:

Jean-François Humbert jean-francois.humbert@upmc.fr

Specialty section:

This article was submitted to

Freshwater Science,

a section of the journal

Frontiers in Environmental Science

Received: 21 June 2019

Accepted: 16 October 2019

Published: 31 October 2019

Citation:

Humbert J-F and Quiblier C (2019)

The Suitability of Chemical Products

and Other Short-Term Remedial

Methods for the Control of

Cyanobacterial Blooms in Freshwater

Ecosystems.

Front. Environ. Sci. 7:176

doi: 10.3389/fenvs.2019.00176
The eutrophication of many freshwater ecosystems due to human activities frequently results in recurrent cyanobacterial blooms (O'Neil et al., 2012). These blooms disrupt the functioning of aquatic ecosystems and their uses, particularly because many species are likely to produce cyanotoxins (Paerl et al., 2016). It has long been known that the control of nutrients provides a sustainable solution to prevent and/or restore ecosystems from eutrophication and therefore from cyanobacterial blooms (Heisler et al., 2008). However, this requires reduced nutrient inputs, which are often complex and expensive to achieve, and the effects may take time to become visible. For these reasons, many managers have invested in short-term remedial solutions that rapidly reduce cyanobacterial concentrations.

The use of short-term solutions (STS) is primarily based on the application of chemical products such as copper sulfate $\left(\mathrm{CuSO}_{4}\right)$ and hydrogen peroxide $\left(\mathrm{H}_{2} \mathrm{O}_{2}\right)$ or on the use of ultrasonic devices. The application of these STS has generated considerable debate within the community of scientists working on cyanobacteria. In France for example, the scientific community has largely agreed not to recommend STS. However, there is still considerable debate internationally, and this issue generated intensive discussion during a special session on the use of STS at the International Toxic Algae Conference held in Nantes, France in 2018. The aim of this opinion paper is to provide further context to why some scientists are concerned about the increasing use of STS.

\section{HOW TO LIVE WITH CYANOBACTERIA?}

Human exposure to cyanotoxins occurs mainly via ingestion of contaminated water. To limit the exposure, monitoring of cyanobacteria and their toxins has been implemented in many developed countries (Figure 1). This monitoring informs users of potential risks and can lead to the exclusion of some activities during bloom periods.

When cyanobacterial blooms occur that are potentially dangerous to human health, three kinds of actions can be implemented (i.e., Paerl, 2018). First, if the goal is to maintain different uses despite the recurrent proliferation of cyanobacteria, STS that rapidly reduce cyanobacterial biomass, can be used. To our knowledge, these STS are mostly used in developed countries to 


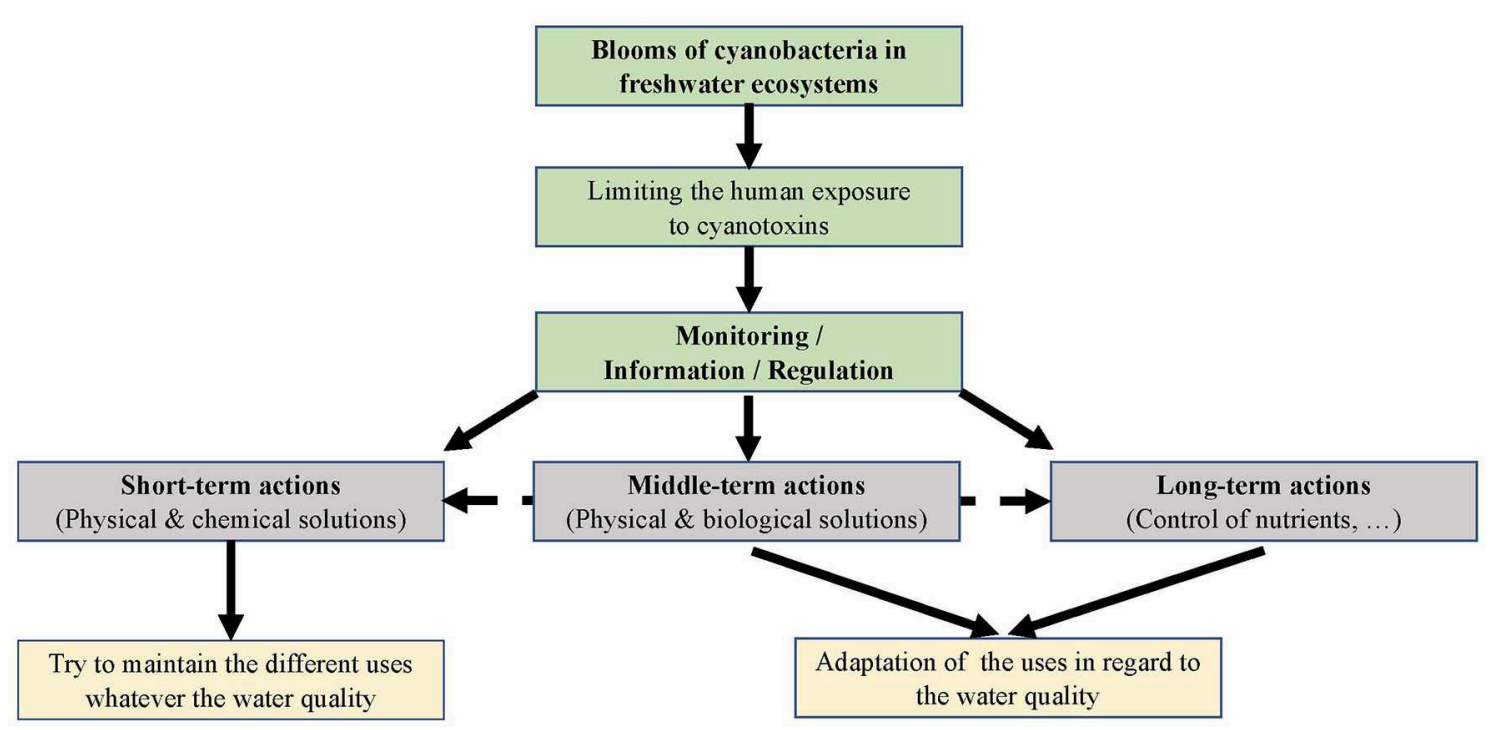

FIGURE 1 | Management scheme for cyanobacterial blooms.

maintain recreational activities in water bodies. Second, various middle-term solutions such as mixing of the water column, the use of compounds that absorb or precipitate phosphorus, or biomanipulation of trophic networks, can be used to limit the development of cyanobacteria. Third, long-term solutions based on the control of nutrient inputs can be implemented that reduce eutrophication and thereby moderate problematic cyanobacterial blooms. These two last strategies require water managers to modify water use by the public while the solutions take effect. For example, temporary swimming closures, or long-term changes in recreational activities, or finding alternative drinking water supplies may be required. It has been recommended that the two first strategies are used in combination with the sustainable protection and/or restoration of freshwater ecosystems (Ibelings et al., 2016).

From a legal perspective in Europe, it appears that the use of chemical products or ultrasound treatments in water bodies do not require specific authorization and there is little or no regulation of their application in natural environments. In the case of $\mathrm{CuSO}_{4}$ and $\mathrm{H}_{2} \mathrm{O}_{2}$, these two products are classed as Type 2 biocides and algaecides by the European Chemical Agency (see https://echa.europa.eu/fr/information-on-chemicals/biocidalproducts), but their use in natural environments is not clearly defined. This regulation mainly concerns the use of $\mathrm{H}_{2} \mathrm{O}_{2}$ in swimming pools or other closed basins, and recommendations have been made to limit discharges into natural environments. The European regulation $n^{\circ} 528 / 2012$ on the biocidal use of copper sulfate [https://circabc.europa.eu/sd/a/b3b0f644-6e3b4ac4-8c5f-2bba6e5cf9c6/Copper\%20sulphate\%20(assessment $\% 20$ report $\% 20$ as $\% 20 \% 20$ finalised\%20on\%2027.09.13).pdf] only concerns the industrial use of this product and recommends limited discharges into natural environments. Finally, we were not able to find any administrative authorization related to the use of ultrasound devices in freshwater ecosystems in Europe.

\section{IS IT POSSIBLE TO ASSESS THE REAL IMPACT OF SHORT-TERM REMEDIAL SOLUTIONS ON ECOSYSTEMS?}

We have identified several potential problems in the assessment of the impact of STS on ecosystem biodiversity and functioning:

- Some of these impact studies have been performed by research teams who were involved in the development of these products and/or have financial links with private companies involved in their development and/or implementation. As it has been already described in medical research, such situations can generate potential conflicts of interest (Bekelman et al., 2003; Resnik, 2007).

- We are concerned about the difficulties in assessing the impact of STS on freshwater ecosystems by using laboratory experiments. These experiments focus on a limited number of target organisms compared to the biodiversity present in natural freshwater ecosystems. It is well-known that susceptibility to a substance varies significantly between species, even if they belong to the same class (Ma et al., 2002, 2006). Additionally, the target species chosen for these tests are not always those that are the most likely to be affected by the treatment. For example, there are no data on the impact of $\mathrm{H}_{2} \mathrm{O}_{2}$ on the bacterial communities in aquatic ecosystems despite the well-known bactericide activity of this product (Colobert et al., 1962). Bacteria play a key role in aquatic nutrient cycles (Azam et al., 1983), therefore enhancing knowledge on the effect of $\mathrm{H}_{2} \mathrm{O}_{2}$ on bacterial communities should be a priority.

- Extrapolating, data obtained from laboratory or mesocosm experiments to natural environments is difficult because aquatic organisms are subject to much greater stresses in their 
natural environment. This has marked consequences on their responses to an additional stress (Heugens et al., 2001).

These concerns highlight the difficulties of carrying out an $a$ priori assessment of the potential impacts of STS on biodiversity and freshwater ecosystem functioning. They are similar to those already widely acknowledged for the assessment of the environmental impacts of pesticides (see, for example, Forbes et al., 2008). To overcome these limitations and difficulties, long-term monitoring of ecosystems where the solutions have been applied should be systematically implemented (Vijver et al., 2017). Such monitoring programs are the most robust way to detect the long-term effects of these treatments, especially if they lead to disturbances that do not affect the main uses of water bodies. However, when looking at the current situation in France, most of the ecosystems where these solutions have been applied are not subject to any long-term ecological monitoring. For example, of the 35,000-500,000 water bodies (surface $>0.01$ hect) identified in France (Bartout and Touchard, 2013), only 435 are monitored for their ecological status under the Framework Water Directive.

\section{ENSURING SUITABLE PRACTICES IN THE APPLICATION IN THE FIELD OF SHORT-TERM SOLUTIONS}

We have identified several difficulties in the field application of STS. The first concerns the estimation of optimal doses to be applied to prevent or reduce the development of cyanobacterial blooms while limiting the adverse effects on non-target organisms. In respect to ultrasound, Lürling et al. (2016) noted that significant differences occurred between the protocols applied in the laboratory and those implemented in the field according to the characteristics of the ecosystems and the equipment used. While it is relatively straight forward to define the optimal chemical doses during laboratory experiments, it is much more difficult to do so in natural environments. Doses depend on the ecosystem characteristics (its morphometry for example) and environmental variables that may interfere with treatment efficacy. Barrington et al. (2013) and Drábková et al. (2007) have shown that the optimal dose for $\mathrm{H}_{2} \mathrm{O}_{2}$ depends on the volume of the water body, the phytoplankton biomass, the type of cyanobacteria (for example, the size of the colonies) and the UV radiation/light intensity. As a result, the recommendations in terms of effective doses vary considerably in the literature, from 2 to $20 \mathrm{mg} . \mathrm{L}^{-1}$ (Matthijs et al., 2012; Lürling and Tolman, 2014; Kansole and Lin, 2017). These findings emphasize that prior to chemical application a detailed knowledge of each ecosystem is needed.

Finally, at least in France, the application in the field of STS is not subject to any control, which may result in practice that are unsafe or lead to ecosystem health decline. For example, it is recommended that application of $\mathrm{CuSO}_{4}$ is avoided during cyanobacterial blooms to prevent the release of free toxins into the water. However, in many cases this recommendation is not followed (see for example, Bourke et al., 1983; Jancula and Marsalek, 2011, and a report produced by the French Water Agency describes numerous cases of inappropriate use of $\mathrm{CuSO}_{4}$ : http://documentation.pole-zhi.org/ doc_num.php?explnum_id=344).

\section{IS THE USE OF SHORT-TERM SOLUTIONS COMPATIBLE WITH THE IMPLEMENTATION OF LONG-TERM ACTIONS AIMED AT REDUCING NUTRIENT LOAD IN AQUATIC ECOSYSTEMS?}

STS are considered by some researchers and managers of water bodies as a complementary option to long-term actions for the control of nutrient inputs. However, there is often competition between the use of STS and the implementation of long-term actions. STS constitute a lucrative and growing market for many companies that attempt to convince managers of freshwater ecosystems that the use of these solutions will lead to rapid results. Consequently, many water managers prefer to invest in STS instead of implementing long term actions aimed at reducing nutrient inputs.

STS are presented as less expensive than long-term solutions but their cost is frequently underestimated because they must be repeated several times during the summer season and for many years [for example see Olivier (2018) for the Brittany region]. Moreover, poor efficiency means that water managers frequently test multiple STS with little consideration for the cumulative effects on ecosystems. For example in a waterbody located near Paris, the following actions have been applied successively in the past 15 years: lime, $\mathrm{CuSO}_{4}$, installation of aerators, barley straw boots, addition of bacteria, installation of nets to protect one beach and construction of a wall to protect another beach. Consequently, in the context of limited budgets, especially when the management of water bodies belongs to small municipalities, these STS clearly compete with long-term actions for funding and resources.

\section{CONCLUSIONS}

Because of (i) the many uncertainties about the long-term environmental impacts of STS application on biodiversity and ecosystem functioning and (ii) the costs of these STS and consequently the financial competition between these solutions and the measures that reduce the eutrophication, we encourage scientists and managers of freshwater ecosystems negatively impacted by cyanobacterial blooms to consider a more cautious approach when recommending the application of STS, particularly when they aim to maintain non-essential uses such as recreational activities.

To better understand the reasons for the failures of the strategies implemented to combat eutrophication and to allow for the emergence of new paradigms that lead to the improvement the management of aquatic ecosystems, we believe that it is necessary to better implement transdisciplinary research approaches using sociologists, ecologist and economists as well as managers and users of these ecosystems, as it has been done for other issues (i.e., Lang et al., 2012). In this context, we will work 
for example on the development of a territorial management approach for a set of water bodies where their uses and the actions implemented for their protection/restoration will be defined by cooperative approaches according to (i) the water quality and ecological health of these ecosystems and (ii) the users and managers expectations (Project GESTERR funded by the Britany Region and the Water agency Loire-Bretagne that will start in January 2020).

Finally, the issue of cyanobacterial blooms management has mainly concerned developed countries and some developing countries like China and Brazil. However, human population growth and associated activities means that an increasing number of developing countries, in particular on the African continent, will face increasing problems with cyanobacterial blooms. In these countries where numerous people have a limited access to

\section{REFERENCES}

Azam, F., Fenchel, T., Field, J. G., Gray, J. S., Meyerreil, L. A., and Thingstad, F. (1983). The ecological role of water-column microbes in the sea. Mar. Ecol. Prog. Ser. 10, 257-263. doi: 10.3354/meps010257

Barrington, D. J., Reichwaldt, E. S., and Ghadouani, A. (2013). The use of hydrogen peroxide to remove cyanobacteria and microcystins from waste stabilization ponds and hypereutrophic systems. Ecol. Eng. 50, 86-94. doi: 10.1016/j.ecoleng.2012.04.024

Bartout, P., and Touchard, L. (2013). L'inventaire des plans d'eau français: outil d'une meilleure gestion des eaux de surface. Ann. Geo. 691, 266-289. doi: 10.3917/ag.691.0266

Bekelman, J. E., Yan Li, A. B., and Gross, C. P. (2003). Scope and impact of financial conflicts of interest in biomedical research. J. Am. Med. Assoc. 289, 454-465. doi: 10.1001/jama.289.4.454

Bourke, A. T. C., Hawes, R. B., Neilson, A., and Stallman, N. D. (1983). An outbreak of hepato-enteritis (the Palm Island mystery disease) possibly caused by algal intoxication. Toxicon 21, 45-48. doi: 10.1016/0041-0101(83)90151-4

Colobert, L., Nofre, C., Montagnoli, B., and Cier, A. (1962). Bactericidal activity of chemical systems productive free hydroxyle radicals on Escherichia coli, mechanism of bactericidal activity of hydrogen peroxyde and ascorbic acid. Ann. Inst. Pasteur. 102:278.

Drábková, M., Admiraal, W., and MarŠálek, B. (2007). Combined exposure to hydrogen peroxide and light - selective effects on cyanobacteria, green algae, and diatoms. Environ. Sci. Technol. 41, 309-314. doi: 10.1021/es060746i

Forbes, V. E., Calow, P., and Sibly, R. M. (2008). The extrapolation problem and how population modeling can help. Environ. Toxicol. Chem. 27, 1987-1994. doi: 10.1897/08-029.1

Heisler, J., Glibert, P., Burkholder, J., Anderson, D., Cochlan, W., Dennison, W., et al. (2008). Eutrophication and harmful algal blooms: a scientifc consensus. Harmful Algae 8, 3-13. doi: 10.1016/j.hal.2008.08.006

Heugens, E. H. W., Hendricks, A. J., van Straalen, N. M., and Admiraal, W. (2001). A review of the effects of multiple stressors on aquatic organisms ans analysis of uncertainty factors for use in risk assessment. Crit. Rev. Toxicol. 31, 247-284. doi: 10.1080/20014091111695

Ibelings, B. W., Fastner, J., Bormans, M., and Visser, P. M. (2016). Cyanobacterial blooms: ecology, prevention, mitigation and control: editorial to a CYANOCOST special Issue. Aquat. Ecol. 50, 327-331. doi: 10.1007/s10452-016-9595-y

Jancula, D., and Marsalek, B. (2011). Critical review of actually available chemical compounds for prevention and management of cyanobacterial blooms. Chemosphere 9, 1415-1422. doi: 10.1016/j.chemosphere.2011.08.036

Kansole, M. M. R., and Lin, T. F. (2017). Impacts of hydrogen peroxide and copper sulfate on the control of Microcystis aeruginosa and MC-LR and the inhibition of MC-LR degrading bacterium Bacillus sp. Water 9:255. doi: 10.3390/w9040255

Lang, D. J., Wiek, A., Bergmann, M., Stauiffacher, M., Martens, P., Moll, P., et al. (2012). Transdiciplinary research in sustainability science: practice, treated water, the sustainable management of water bodies is a crucial issue and the uncontrolled use of STS might have dramatic consequences on human and environmental health.

\section{AUTHOR CONTRIBUTIONS}

J-FH and CQ have written the paper together.

\section{ACKNOWLEDGMENTS}

We would like to offer our sincere thanks to Ken Ryan (University of Wellington, New Zealand) and Susie Wood (Cawthron Institute, New Zealand) for their very constructive suggestions that have allowed us to improve this manuscript. We would like also to thank the reviewer for his/her comments. principles, and challenges. Sustain. Sci. 7, 25-43. doi: 10.1007/s11625-0110149-x

Lürling, M., and Tolman, Y. (2014). Beating the blues: Is there any music in fighting cyanobacteria with ultrasound? Wat. Res. 66, 361-373. doi: 10.1016/j.watres.2014.08.043

Lürling, M., Waajen, G., and de Senerpont Domis, L. N. (2016). Evaluation of several end-of-pipe measures proposed to control cyanobacteria. Aquat. Ecol. 50, 499-519. doi: 10.1007/s10452-015-9563-y

Ma, J., Lu, N., Qin, W., Xu, R., Wang, Y., and Chen, X. (2006). Differential responses of eight cyanobacterial and green algal species, to carbamate insecticides. Ecotoxicol. Environ. Safety 63, 268-274. doi: 10.1016/j.ecoenv.2004.12.002

Ma, J., Zheng, R., Xu, L., and Wang, S. (2002). Differential sensitivity of two green algae, Scenedesmus obliqnus and Chlorella pyrenoidosa, to 12 pesticides. Ecotoxicol. Environ. Safety 52, 57-61. doi: 10.1006/eesa.2002.2146

Matthijs, H. C. P., Visser, P. M., Reeze, B., Meeuse, J., Slot, P. C., Wijn, G., et al. (2012). Selective suppression of harmful cyanobacteria in an entire lake with hydrogen peroxide. Wat. Res. 45, 1460-1472. doi: 10.1016/j.watres.2011.11.016

Olivier, D. (2018). Recensement et Analyse des Suivis et Actions Conduits dans les Plans d'eau en Bretagne et Mise en Perspective Pour l'action. Mémoire de Master II Gestion des Habitats et des Bassins Versants, Université de Rennes 1:69.

O'Neil, J. M., Davis, T. W., Burford, M. A., and Gobler, C. J. (2012). The rise of harmful cyanobacteria blooms: The potential roles of eutrophication and climate change. Harmful Algae 14, 313-334. doi: 10.1016/j.hal.2011.10.027

Paerl, H. W. (2018). Mitigating toxicplanktonic cyanobacterial blooms in aquatic ecosystems facing increasing anthropogenic and climate pressures. Toxins 10:76. doi: 10.3390/toxins10020076

Paerl, H. W., Gardner, W. S., Havens, K. E., Joyner, A. R., McCarthy, M. J., Newell, S. E., et al. (2016). Mitigating cyanobacterial harmful algal blooms in aquatic ecosystems impacted by climate change and anthropogenic nutrients. Harmful Algae 54, 213-222. doi: 10.1016/j.hal.2015.09.009

Resnik, D. B. (2007). Conflict of interest in scientific research related to regulation of litigation. J. Philos. Sci. Law 7, 1-12. doi: 10.5840/jpsl2007722

Vijver, M. G., Hunting, E. R., Nederstigt, T. A., Tamis, W. L., van den Brink, P. J., and van Bodegom, P. M. (2017). Postregistration monitoring of pesticides is urgently required to protect ecosystems. Environ. Toxicol. Chem. 36, 860-865. doi: 10.1002/etc.3721

Conflict of Interest: The authors declare that the research was conducted in the absence of any commercial or financial relationships that could be construed as a potential conflict of interest.

Copyright (c) 2019 Humbert and Quiblier. This is an open-access article distributed under the terms of the Creative Commons Attribution License (CC BY). The use, distribution or reproduction in other forums is permitted, provided the original author(s) and the copyright owner(s) are credited and that the original publication in this journal is cited, in accordance with accepted academic practice. No use, distribution or reproduction is permitted which does not comply with these terms. 